\title{
An Examination Of Ethiopia's Anti -Terrorism Proclamation On Fundamental Human Rights
}

\author{
Peter Sekyere \\ Brock University \\ Bossman Asare \\ University of Ghana
}

doi: 10.19044/esj.2016.v12n1p351 URL:http://dx.doi.org/10.19044/esj.2016.v12n1p351

\begin{abstract}
Since the enactment of Ethiopia's Proclamation on Anti-Terrorism in August 2009, at least11 journalists have been convicted, each sentenced to at least 10 years imprisonment. There are concerns that the proclamation limits the right to freedom of thought, opinion and expression, provided for in Ethiopia's Constitution. Through the lens of the right to freedom of thought, opinion and expression, the paper argues that Ethiopia's Anti-Terrorism Proclamation violates the human rights of people within its jurisdiction. It finds that there is a real potential for the state to crack down on political dissent in governance and curtail the growth of democracy in Ethiopia.
\end{abstract}

Keywords: Freedom of thought, opinion and expression, Ethiopia, AntiTerrorism, and Human Rights

\section{Introduction}

International law obliges states to repress and prevent terrorism but it has failed to authoritatively define the concept due to divergent political interests (United Nations General Assembly Adopts Global CounterTerrorism Strategy, 2006). The contestation has been whether or not the definition should recognize the legitimacy of armed struggles by national freedom fighters (Steiner, Alston and Goodknow, 2008). With international law largely depending on individual countries for implementation on issues like counterterrorism, one should expect individual governments to adopt policies and laws consistent with certain core ideologies and internationallyacceptable best practices (Asare, 2016). However, various states, in their quest to deal with terrorism, have defined the concept in their own ways. This has allowed some states to define it in their own terms to suit the true, and perhaps parochial, agenda of governments. Whereas some definitions are comprehensive, and grants due regard to the effective protection of human 
rights, some are quite vague and problematic. The definition of terrorism in Ethiopia's domestic legislation is one of such problematic ones.

In August 2009, Ethiopia enacted legislation to counter terrorism Anti-terrorism Proclamation no. 625/2009. The enactment results from an acknowledgment that terrorism is a threat to human rights, peace and security of not only the people in Ethiopia, but to the rest of the world (Preamble of Ethiopia Anti-Terrorism Proclamation, 2009). However, since the passage of the law, many journalists and opposition politicians have been convicted, with each sentenced to a prison term of not less than 10 years (Human Rights Watch Submission on Ethiopia 2012). The conviction and imprisonment of journalists have directly impacted on the rights of the people, particularly the right to freedom of expression, which is one of the pillars on which states build functional democracies.

Atypically, though the legislation has been passed and some 'terrorists' have been convicted, terrorist attacks on Ethiopia have been on the rise. Ethiopia has recorded at least six terrorist attacks since the passage of the law and the situation seems to be getting worse. Criticism of the antiterrorism law of Ethiopia is rife. Fundamentally, the claims are that, the definition of terrorism or a terrorist is too broad and that the law is politically motivated to crack down on political dissent, and hence a limitation on the potential for true democracy and good governance in Ethiopia.

This paper seeks to examine the influence of this anti-terrorism legislation in Ethiopia, on the basis of the right to freedom of thought, opinion and expression. Although Ethiopia's Constitution recognizes these basic freedoms, the anti-terrorism legislation seems to negate the goals of Article 29 of the same Constitution. This Article is the right of Thought, Opinion and Expression. This paper seeks to answer a specific question: What influence has Ethiopia's anti-terrorism proclamation got on the right to freedom of expression, opinion and thought since its enactment in 2009? The anti-terrorism legislation appears to have a direct impact on the right of thought, opinion and expression (Article 29 of Ethiopia Constitution, 1994). Hence the paper seeks to uncover what the effects and implications are on the country and its peoples. The paper also discusses what makes the right so important that it requires jealous preservation. These will be preceded by the methodology and theoretical framework.

The paper assesses Ethiopia's Anti-terrorism Proclamation and argues that, not only is the definition of terrorism problematic, but also the implementation of the law continues from the weak ends of the law, and makes the Ethiopian situation rife for the violation of the right of thought, opinion and expression. This paper is divided into three main parts. First the paper examines the background of Ethiopia upon which the enactment of the legislation is necessary. It discusses the context of Ethiopia as a strong state 
in a weak region-the Horn of Africa. In the second part, we examine the right of thought, opinion and expression from the Ethiopian Constitution and juxtapose it with that of the International Covenant on Civil and Political Rights (ICCPR), which Ethiopia has ratified. The paper then discusses the right of thought, opinion and expression before and after the Proclamation. Finally, we look at the importance of the right to freedom of thought, opinion and expression and why it should be protected, promoted and fulfilled by the state. Here, 'the constitution' will refer to the Constitution of the Federal Democratic Republic of Ethiopia-which will simply be referred to as Ethiopia. The right in question is provided for in Article 29 of the Ethiopian Constitution as the right of thought, opinion and expression.

Methodologically, the paper used existing literature in the form of text books, journal articles, and internet sources of academic relevance and reports of some international Non-Governmental Organizations and Intergovernmental Governmental Organizations such as the United Nations, on the situation in Ethiopia. In addition, the Anti-terrorism proclamation and the Ethiopian Constitution serve as critical sources of reference materials for this paper. In its analysis, the paper does a diachronic analysis of comparing the Ethiopian situation before and after the passage of the anti-terrorism legislation. This elucidates the influence of the proclamation and its implementation.

\section{Theoretical Framework}

Human rights theory provides justification for the protection of human rights (Donnelly 1993; Orend 2002). The Universalist conception of human rights holds that all human beings have dignity and therefore require protection on the basis of that (Asare 2011). ${ }^{129}$ States as duty bearers (Nickel, 2007) in human rights theory are required by international human rights law to protect the rights of all people in their territory and subject to their jurisdiction (Duffy, 2007). The protection of right holders from violations involves protection from both state actors and non-state actors, whether lawful or unlawful groups such as transnational corporations or terrorist organizations respectively.

In the post-Cold War era, marked by the events of September 11 2001, terrorist organizations have become key violators of human rights through their vicious attacks on civilians and state property in order to achieve specific ends (Duffy, 2007). While human rights theory expects states to protect people in their jurisdiction, such state efforts are expected to

\footnotetext{
${ }^{129}$ This is alluded to by nearly all human rights instruments at universal, regional and national levels. For instance, the Universal Declaration of Human Rights, the International covenant on civil and Political Rights (ICCPR), the Banjul Charter and the Ethiopia constitution.
} 
be in conformity with international human rights standards, identified by the ICCPR. The devastating consequences of terrorism testifies to its direct impact on human rights (Human Rights, Terrorism and Counter Terrorism, 2015). It is recognized that the fight against terrorism has the potential of violating human rights. In effect, states are required to strike a balance between effective counter terrorism efforts and protecting human rights to ensure that human rights are not relegated to the background in the fight against terrorism.

While it is commendable that the government of Ethiopia has responded effectively to counter terrorism through the enactment of the proclamation, its definition of terrorism has been criticized for being overly broad, allowing the state to achieve political ends with its interpretation and implementation (UNHCHR grills Ethiopia on anti-terror law, 2011). A major political end identified by critics is the breach on the right of thought, opinion and expression through the implementation of the proclamation (UNHCHR grills Ethiopia on anti-terror law, 2011). The Ethiopian Constitution rightfully acknowledges this as a democratic right as it enhances civil participation in the governance of the state. ${ }^{130}$ The right of thought, opinion and expression is very vital for the democratic development of a society. It is considered fundamental to the full development of the individual in the polity and a requirement for the realization of democratic principles such as accountability and transparency (UN Human rights Committee General Comment 34, ICCPR, YEAR). As a right in itself, it enables individuals to participate in the governance of their community and enhances the enjoyment of related right provisions such as freedom of assembly and association, religion and the protection of minority rights, fair trial, and among others (UN Human rights Committee General Comment 34, ICCPR, 2011). The importance of this right, like all others, makes its violation gravely problematic, especially when it is a case of direct violation of rights by the state that should rather be the protector.

\section{Terrorism on the Horn of Africa}

The Horn of Africa has for a long time been an area of high security concern not only for Africa but for the rest of the world, particularly the United States (Khadiagala et. al. 2004:p1). During the era of the Cold War geopolitics, both the United States (US) and the Soviet Union (SU) were interested in asserting some influence over the area. Both countries sought to spread their respective capitalist and socialist ideologies, and for the protection of security and oil interest of the US especially. The US needed

\footnotetext{
${ }^{130}$ This is contained in part two of the Constitution which provides the right under "Democratic Rights"
} 
to secure the Gulf of Aden for safe passage of its oil vessels from the Arabian part of the area. The Horn of Africa has been of particular importance to the US for its proximity to the Persian Gulf region and for the protection of US oil interest in emergency situations (Dagne, 2002: p 6.). The presence of Al Qaeda and Al Shabaab pose a serious threat to the US interests in that region (Ploch, 2010). Djibouti, for instance, has become a major refueling station for US military aircrafts (Dagne, 2002: p 6). The presence of pirates on the high seas of the Gulf of Aden has been of concern for a long time though in recent times their strength has waned dramatically.

Composed of Eritrea, Djibouti, Sudan, South Sudan, and Ethiopia, the Horn of Africa is characterized by weak or failing states, most of which are further plagued by internal conflicts, armed attacks and political instability. Sudan has been engaged in internal armed conflict for many years, culminating in the birth of South Sudan. Immediately beneath the horn is Kenya. Kenya has suffered many terrorist attacks yet its government has not been strong enough to prevent more attacks, with the most recent ones occurring in September 2013 in the Westgate Mall attacks by Al Shabaab that claimed about 27 lives, and the March 2015 Garissa University College attack by same that claimed about 150 lives. In 1998, the US embassies in Nairobi, Kenya and Dares Salam, Tanzania were bombed. About 200 lives were lost and another 4000 were injured. Again in 2002, al Qaeda-backed terrorists attempted to shoot down an Israeli airliner after bombing a hotel in Mombasa, Kenya (Khadiagala et. al. 2004: p2). A little over a decade before this, 18 US soldiers were killed in Somalia in 1993 in what became known as the Somali debacle. Djibouti, as a high point of entry to the horn, has been a weak state which has not been able to patrol its coast line effectively. Hence these countries have increasingly become a safe haven for terrorist groups such as Al Qaeda and Al Shabaab.

Yet it is worth noting that among the states on the horn of Africa, Ethiopia seems to have a more stable security force in place. As a strong state in a weak region, Ethiopia has had its own generous share of terrorist attacks. In recent years, armed groups have committed a number of bombings and other attacks in Ethiopia or on Ethiopia's diplomatic missions. Two attacks were recorded in 2008. In May 2008, an explosion on a minibus in Addis Ababa, killed three people. The attack was on the eve of national day celebrations. In October 2008, the Ethiopia trade mission in Somalia was one of the targets of a multiple suicide bombing that claimed about 20 lives (An Analysis of Ethiopia's Draft Anti-Terrorism Law, 2009). Many more attacks have been recorded. 


\section{The Right of Thought, Opinion and Expression in Ethiopia.}

The 1994 Constitution of Ethiopia provides for the right of thought, opinion and expression in Article 29 but not without doing so in a manner that raises concerns among the human rights fraternity. The mere constitutional provision for this right, among others, sets the legal basis for people to lay claims to their rights. However, it has not been without serious drawbacks. Starting from the preamble, it sets a duty on the state only to fully respect rather than to protect the 'individual and people's fundamental freedoms and rights”' (Preamble of Ethiopia’s Constitution par. 2, 1994). Before the provision of Article 29, the Constitution distinguishes between human rights and freedoms on the one hand, and human rights and democratic rights on the other hand, in Article 10.

Whereas 'human rights' are those that emanate from the very nature of human kind and therefore inviolable and inalienable, 'democratic rights' are those that derive from the relationship between people and the state. Therefore democratic rights "shall be respected." This categorization of rights is very important for two reasons. First it sets a scope and magnitude of duty on the state by defining which set of rights are, on the one hand, inalienable and inviolable, and on the other hand, which set of rights are only to be respected. Thus, the extent of state liability. Second, it tends to rank human rights higher than democratic rights. Impliedly, it permits the state to prioritise human rights and probably pay little or no attention to democratic rights, if not to disregard it completely. In esence, the Ethiopian government could deliberateley undermine attempts at political participation by certain segments of the society and political parties. While political participation by the masses has become an orthodoxy in governanace and public management, there is a clear indication that, the Ethiopian state is subverting a practice which is integral to democratic governance.

Despite the categorization, it still does not identify the Ethiopian state's duties in unambiguous language. Rather, it only mentions that human rights and freedoms are inalienable and inviolable but fails to add what duties the state has in ensuring it. Under the human and democratic rights, the Constitution only sets the state the duty to respect, although the ICCPR obliges states to go beyond respect, to ensure the fulfillment of human rights (UN ICCPR Article 2(1), 1966). It is in the category of democratic rights that the right of thought, opinion and expression is provided.

Article 29 sets out the specific provisions for the right in question. Like the ICCPR, it provides for the right to hold opinions, seek and have access to information among others. It further provides the media legal protection to ensure free flow and easy access to information as well as publishing social and political content. It also sets a limitation on the media for the purpose of protecting the reputation of others, avoiding propaganda 
for war and protecting the youth. A few observations can be made on the basis of this Article. First, the identification of, and singling out the youth for, protection under this article may be discriminatory because state provision of safety and security of persons under its jurisdiction shoud be based on the principle of equality and non discrimination. Second, the categorization of the right under democratic rights makes it less secured for the people since democratic rights are only to be respected. Third, the special protection of the media is commendable since the media helps the people in advancing this very right in question. The educational role of the media is vital to the formation of individual and group opinions.This is important for the democratic development of Ethiopia as the right to freedom of opinion and expression is necessary for the realization of important democratic principles like transparency and accountability (UN Human Rights Committee General Comment No. 34, par. 3, 2011).

\section{International Law's Role in the Promotion of Ethiopia's Right of Thought, Opinion and Expression}

Besides the constitutional provisions on human rights and democratic rights, the people under the jurisdiction of Ethiopia have access to the provisions in the African Charter on Human and Peoples' Rights, ICCPR and International Covenant on Economic, Social and Cultural Rights (ICESCR) since the state has ratified these global and continental human rights conventions. This effort of the Ethiopia government is commendable for the advancement of human rights. However, ratification of a human rights treaty is not the same as effective protection, promotion and development of human rights. The issue of the status of enforcement of such treaties at the domestic level is of critical importance. Further, the attitude and commitment of the govenment in the promotion and enforcement of human rights provisions from both internal and external sources are equally vital. In this regard, the methods of application of international human rights laws within domestic courts is necessary.

Per the provision in Article 9 (4) of the Constitution, Ethiopia is a monist state. It provides that, "all international agreements ratified by Ethiopia are an integral part of the law of the land." Hence there is no need for any special legislative act to be passed in order to give or provide a domestication effect before international law can be applied in domestic courts. In contrast to dualist states, monist states are those in which both domestic and international law have identical sources, subjects and substantive content. Dualist states, however, are those that distinguish between municipal law and international law and claim that none can nulify the other (Adinew, 2002). Hence in Ethiopia, both national and international law are not considered separate regimes. 
While the Ethiopia government can be commended for its monist approach to domesticating international human rights law, the issue of hierarchy between national and international law has not been completely resolved. To begin with, the Constitution has set a hierachy between human rights and democratic rights. The ICCPR does no such distinction. Hence there is the need to resolve the issue of hierarchy between domestic and international law since Ethiopia is a monist state. This would enable us know which law can be applied under which circumstance.

Although both domestic and international law are not considered as separate regimes in Ethiopia, Article 9 (1) of the Constitution unequivocally states that "the Constitution is the supreme law of the land. Any law, customary practice or a decision of an organ of state or a public official which contravenes this Constitution shall be of no effect.' This means that the provisions of the Ethiopia Constitution occupies a primary position of priority. This effectively means that, although a monist state, the provisions of the Constitution occupies a 'supreme' position to any other law. Yet the Constitution further provides in Article 13 (2) that "The fundamental rights and freedoms specified in this Chapter shall be interpreted in a manner conforming to the principles of the Universal Declaration of Human Rights, International Covenants on Human Rights and International instruments adopted by Ethiopia.",

This makes for ambiguity and allows for some extensive descretion in the interpretation and enforcement of the law. This is highly problematic for a country in which judicial independence and efficiency are uncertain (Human Rights Watch Submission on Ethiopia 2012). For instance, human rights are only said to be inviolable and inalienable and democratic rights are only to be respected. Yet international human rights law obliges state parties not only to respect but to ensure that all people, within their territory and subject to their jurisdiction, are protected in accordance with international human rights law (UN ICCPR Article 2 (1), 1966). This requires the state party to go beyond respect for human rights to take practical steps such as public policies and programs to enable the people know and enjoy their rights and freedoms (UN Human Rights Committee General Comment No. 3, Par.1, 1991).

How will a victim in Ethiopia seek redress? The state would certainly argue that its duty under the Constitution is to respect. Although the provision is to be interpreted in the light of international law, this paper has established that what the Constitution says is supreme. Hence, in Ethiopia, what international law says is effective in so far as it is in conformity with domestic law. Generally, as the fundamental law of the land, the Ethiopian Constitution takes presedence over all the laws be it domestic or international although the state still claims to be a monist state. 
Another dimension to this vagueness is that, it is a deliberate act of the government to create such a contradiction so that the onus to resolve it shall fall on the judiciary. Indeed the role of the judiciary as an arm of government is in line with matters including this very issue. Globally, it is considered a good governance best practice for political systems to have a judiciary that exercises its power of judicial review independently. Further, reliance on the judiciary for the protection and adavancement of human rights, through interpretation of laws, rules and regulations is widely recommended. Nonetheless, the judiciary in Ethiopia is hardly independent of the influences of the executive and, in fact, the judiciary has a history of complicity with government in human rights abuses (Adinew, 2002). Essentially the courts in Ethiopia cannot be trusted to play this imporrtant role effectively in a manner that will advance the cause of human rights for the people of Ethiopia.

\section{Ethiopia Before the Proclamation}

Before the passage of the Anti-Terrorism Proclamation, there was no clear legislation in Ethiopia that could criminalise the activities of actors in the media and political opponents to the government apart from those specific conditions under which the right of thought, opinion and expression could be restricted. However, journalists and politicians who were critical of the government were not at ease to freely express themselves (UNHCHR grills Ethiopia on Anti-terror law, 2011). Government spokespersons as well as government officials consistently refused to respond to queries and inquiries of private press since they were often critical of government. Only the state owned media had access to government business. As such the accuracy of information on government business could not be verified by the private media.Often they were presented to fit the wishes of government (Country Reports on Human Rights Practices: Ethiopia 2003). Hence the publications of private press were often inaccurate and uncertain at best.

Around this time, the major basis upon which the media were sunctioned were parody, dissemination of false information and the violation of press law. Sentences were for a relatively short period. Besides, bails were readily granted. For instance, Gizaw Taye Wordofa (Editor of Lamrot), Melese Shine (Editor of Ethop newspaper and magazine), and Tsegaye Ayalew (Editor-in-chief of Genanaw), were arrested for publishing allegedly offensive material to the public, publishing defamatory article on the Prime Minister and for unannounced charges respectively. However, they were granted bail within a year (Country Reports on Human Rights Practices: Ethiopia 2003). Also, Robel Mitiku (editor-in-chief of Goh), was detained without charges for a few months, but freed after posting bail of $\$ 1,200$ (Country Reports on Human Rights Practices: Ethiopia 2003). 
Essentially, much of the restriction to the right in question was with the practical application of the existing law. However, there was no clear legal restriction on the constitutional provisions. This enabled journalists and opposition politicians to be more critical of the government. The practical application of the lawful provisions restricting the right of expression was itself a basis for even more criticism on the government. Hence, amidst detentions in prison facilities, people still persued their right of thought, opinion and expression.

\section{Counter Terrorism in Ethiopia- An Analysis and Interpretation of the Bill}

Terrorism has been widely condemned and all states have been urged to take action to prevent and counter terrorism (United Nations General Assembly Adopts Global Counter-Terrorism Strategy, 2014). Terrorism violates fundamental human rights such as the right to life, the right to development, freedom from fear and expression among many others (Duffy, 2007). Therefore, on the basis of the several attacks Ethiopia has suffered, a legislation to counter terrorism is a step in the right direction, particularly as a state on the Horn of Africa as it is notorious for its security concerns.

At the international level, there is no standard definition for terrorism. Hence different institutions and states have different definitions for the concept. Defining terrorism is important to the extent that it determines actions and inactions that may be defined as acts of terrorism and therefore punishable. A number of definitions pertain from several states and intergovernmental organizations, such as the African Union. For instance, the US alone has at least three definitions of the concept: from the Department of Defense, Federal Bureau of Investigations and the State Department. Despite the many definitions for the concept, certain key themes run through many of them. First, there is a calculated use or threat to use force or violence. Second, the act has a purpose to achieve, often to change the status quo, reverse excessive oppression or to achieve some desires of some individuals or groups. These goals are often political, ideological or religious. Third, it is unlawful. Fourth, it involves injury and destruction to life or property. Fifth, it is a large scale violence or very serious criminal act (Cassese, 2005: p 222). Additionally, there is an unequivocal intention on the part of the 'terrorists' to cause mass murder by attacking soft spots like the market centers and the football stadia where security personnel find difficult to provide security (Asare, 2011).

Essentially, these themes all feature in the definition of terrorism by the African Union and the UN Security Council. The various components in the definition of terrorism above are fairly consistent with this comprehensive definition of the concept by Combs (2011: 5) -“terrorism is a 
synthesis of war and theater, a dramatization of the most proscribed kind of violence-that which is deliberately perpetrated on civilian noncombatant victims-played before an audience in a hope of creating a mood of fear."

As mentioned earlier, there is a proliferation of definitions to the concept owing to the absence of a universally accepted definition. Hence some definitions are problematic. The proclamation on anti-terrorism defines terrorist acts or terrorists as follows:

"whosoever or a group intending to advance a political, religious or ideological cause by coercing the government, intimidating the public or section of the public or destabilizing or destroying the fundamental political, constitutional or economic, or social institutions of the country :

1. causes a person's death or serious bodily injury

2. creates serious risk to the safety or health of the public or section of the public

3. commits kidnapping or hostage taking

4 causes serious damage to property

5. causes damage to natural resources, environmental, historical or cultural heritages

6. endangers, seizes or puts under control, causes serious interferences or disruption of any public service; or

7. threatens to commit any of the acts stipulated under subarticles (1) to (6) of this article; is punishable with rigorous imprisonment from 15years to life or with death”

Other associated provisions which affect the interpretation of this article are discussed in due course. The definition of "terrorist acts" is very broad, consequently impacting directly on many human rights provisions. This paper is limiting its analysis to those that bother on the right of thought, opinion and expression. Per the Proclamation, a peaceful demonstration of protest could amount to an act of terrorism (Human rights watch, 2012). A demonstration of protest often seeks to advance a political, religious or ideological cause of some collective of individuals or groups. A protest march can compel a government to do what it planned not to do or to refrain from its intended actions. It may also destabilize political institutions. The vagueness of the proclamation and its interpretation effectively curtails people's right to express their thoughts and opinions as the Constitution provides for in Article 29. Further, a distinction needs to be made between criminal acts of property destruction and from acts of terrorism. Not all actions defined by the criminal code necessarily amount to terrorism yet the proclamation tends to label the causing of "a person's death or serious bodily injury” or causing "serious damage to property" as an act of terrorism. In such a scenario, the distinction between criminality and terrorist acts becomes blurred, with the latter dominating political discussions and taking 
precedence over the former. Political dissent could also be deemed as an act of terrorism and any organized group of persons or interest group may be termed a terrorist organization and made to suffer a rigorous punishment.

Additionally, the proclamation provides for a more specific provision that bothers on free press. Under the subtitle Encouragement of Terrorism, Article 6 provides that

whosoever publishes or causes the publication of a statement that is likely to be understood by some or all of the members of the public to whom it is published as a direct or indirect encouragement or other inducement to them to the commission or preparation or instigation of an act of terrorism stipulated under Article 3 of this Proclamation is punishable with rigorous imprisonment from 10 to 20 years.

This provision is so broad that any publication could be deemed to be in support of terrorism. A commercial for a peaceful demonstration or that for a political campaign rally would also qualify for punishment under this provision. Of course, different people derive various meanings from reading a given text. Hence this allows for the state to crack down on any activity it deems not in its interest. And with state authorities being those in charge of determining what constitute the national interest at any point in time, it is obvious that this provision is hardly an objective criterion for defining an act deemed to fit the encouragement of terrorism. Therefore it is not surprising that the outcome of such a law is that many journalists and politicians are serving various prison terms in Ethiopia.

\section{Limitations to the right of thought, opinion and expression}

The right of thought, opinion and expression has permissible grounds for limitation and this is duly acknowledged in Article 19 of the ICCPR. Yet it is important that "when a State party imposes restrictions on the exercise of freedom of expression, these may not put in jeopardy the right itself" (UN Human Rights Committee General Comment 34 par.21, 2011). It is difficult to clearly define the Ethiopian case. After the Constitution avoids mentioning that the state has a duty to protect human rights, it mentions in the first paragraph of the proclamation on anti- terrorism that "the right of the people to live in peace, freedom and security has to be protected always from the threat of terrorism.” This makes it unclear whether the proclamation is a limitation on the rights of the people, so that the state would have to provide ample justification for it. Instead, the preamble begins as though the state is acting in line with the active creation of rights for the people. The proclamation actually limits the rights of the people without meeting the 
international criteria for the limitation of the right of thought, opinion and expression.

This paper has emphasized the gap or contradiction in the implementation of both national law and international law in Ethiopia, and how state agents like the judiciary are responsible for resolving and implementing them. In this regard, it is worth noting that the proclamation grants special discretionary powers to some public agencies (Ethiopia Antiterrorism Proclamation, 2009). For instance, Article 13 (a) empowers a police officer to "order people" to remain or evacuate a premise or secluded place. This provision does not set any limitation on the duration to which this police order would hold. Besides it could also imply ordering people to remain in police cell since it is all up to the discretion of the police officer. Under such circumstance, the UN Special Rapporteur recommends that adequate safeguards are put in place to avoid abuse of discretionary powers by public institutions or officials (Special Rapporteur on the promotion and protection of human rights and fundamental freedoms while countering terrorism, 2015). The earlier example clearly pays no attention to the recommendations of the special Rapporteur.

International human rights law provides a clear criterion for the limitations on the right of thought, opinion and expression. It acknowledges that the exercise of the right to hold opinions and expressions carries some duties and responsibilities (UN ICCPR Article 19 (3), 1966). This sets the basis for the legitimization of limitations or restrictions on this right in question. Fundamentally, restrictions should be provided by law and should be necessary (UN ICCPR Article 19 (3), 1966).

\section{Application of the proclamation and its impact on democracy in Ethiopia}

Since the passage of the law, many people, particularly journalists and politicians who are critical of the government have felt the law in practice. In June 2012, a High Court sentenced 24 journalists and opposition politicians to a prison term of not less than 10 years each. The journalists were convicted of conspiracy to commit terrorist acts, participation in a terrorist organization and treason. The politicians belonging to two registered opposition political parties- Unity for Democracy and Justice and All Ethiopian Democratic Party- were found guilty of the same charges as the journalists (Ethiopia: Terrorism Law Decimates Media, 2013; Ethiopia: Terrorism Law Used to Crush Free Speech, 2012).

On January 19, 2012, another High Court convicted three Ethiopian journalists, an opposition leader, and a fifth person for conspiracy to commit terrorist acts, participation in a terrorist organization and money laundering ((Ethiopia: Terrorism Law Decimates Media, 2013; Ethiopia: Terrorism 
Law Used to Crush Free Speech, 2012). Notably, all manner of persons have been convicted so far as they were critical of the government through their activities. Individuals and groups that have been part of demonstrations against the government in one form of the other have faced the controversial and vague anti-terrorism law. It is worth noting that since the proclamation was passed in 2009, all suspects and accused persons under the legislation have been found guilty and have been sentenced (Ethiopia convicts 10 for 'links to Al-Qaeda, 2014).

\section{Influence on the right of thought, opinion and expression}

Although the Constitution provides for this right in question, the antiterrorism legislation has cast a mighty shadow on it so that it is as though no such right exist. It is necessary to recall that the right of thought, opinion and expression is categorized as a democratic right which is only to be respected. Although Article 29 is directly related to other rights and therefore, a limitation on the right affects other related rights, it is clear that the Ethiopia government has chosen to prioritize the fight against terrorism over respecting the democratic rights of the people. This implies that the Ethiopian government has chosen, de facto, to restrict the right of thought, opinion and expression in order to fight terrorism.

As to how this right is being restricted, the cases of arrests and convictions in Ethiopia clearly suggest that not only is the right being suppressed but also being connected to the anti - terrorism legislation to achieve some clandestine goals of the government. Since journalists are being arrested for their criticisms of government and politicians are being jailed for opposing the government through regular political activity as pertains in constitutional democracies, it is clear that government seeks to achieve some arcane political goals. The connection is such that the right of thought, opinion and expression shall be respected so far as it is expressed, either in isolation or in connection with other rights, in a manner that does not injure the desires of the government. If it does, then the anti-terrorism legislation applies immediately to the right holder as conspiring to commit terrorist act or inciting others to commit acts of terrorism and whichever organization to which the individual or the group belong, is defined as a terrorist organization.

In contrast to Article 8(3) which provides for the people's direct political participation, the anti-terrorism proclamation significantly limits political participation. Political participation is not limited to voting in periodic elections but includes influencing public policy through, for instance, public fora, demonstrations, boycotts, and among others. It also involves starting or joining a political party, and contesting in elections. Importantly, it involves expressing ones thoughts and opinions. The basis for 
restricting the right is provided for in both the Constitution and international human rights law.

In the Constitution, it provides that...

6. These rights can be limited only through laws which are guided by the principle that freedom of expression and information cannot be limited on account of the content or effect of the point of view expressed. Legal limitations can be laid down in order to protect the well-being of the youth, and the honor and reputation of individuals. Any propaganda for war as well as the public expression of opinion intended to injure human dignity shall be prohibited by law.

Additionally, the ICCPR provides that limitations to the right should be provided by law and should be necessary. It should be necessary either to protect the rights of others or for the safety of the public (Constitution of Ethiopia Article 19 (3), 1994). Since Ethiopia is a monist state, the discussion can conveniently connect the two provisions. Indeed, the Constitution has provided the legal basis for restriction, as recommended by the ICCPR yet it seems that the fight against terrorism has simply set aside the requirement for any restriction of the said rights. Some journalists have been convicted because their publications are deemed by prosecutors to incite or support terrorism. In essence, they are convicted because prosecutors have an understanding of their publication as one that incites or encourages terrorism and therefore their organizations qualify as terrorist organizations. With a court system largely influenced by the executive branch of government, one can only conclude that the interest of state will prevail in matters that the government has vested interest.

\section{Implications}

From the discussion so far, Ethiopia has presented itself as one with the Constitution providing the necessary provisions for the people to enjoy and consequently receiving the praises of the international community. It further presents itself as a monist state and makes international law an integral part of its laws (Constitution of Ethiopia Article 9 (4), 1994). However, from the enforcement of the proclamation, it is evident that the right of thought and opinion may be exercised by the people but the "expression" is the part that can sent people to jail. Indeed it is inconceivable that anyone's thought and opinions are known by others until they are communicated, let alone be prosecuted for them. Of course when thoughts and opinions are not expressed, they remain with their owners. On the other hand, it is difficult to separate the parts of this right. Thoughts and opinions are informed by expressions of others. As new entrants into the world, we 
are born tabula rasa. Through the expressions of others, which come in the form of education or socialization, we develop our thinking process. For instance, the work of journalists and politicians is an important form of political orientation and education to which our thoughts are developed and the basis for forming opinions. Hence it is difficult to separate the parts to the right under discussion. It is necessary for individual development as well as the perpetuation of society (UN Human Rights Committee General Comment 34 par. 2, 2011).

\section{Ethiopian Government's Response}

Ethiopia claims that its anti-terrorism proclamation draws inspiration from the British Terrorism Act of 1996 (UNHCHR grills Ethiopia on Antiterror Law, 2015) and the American Patriotic Law (Ethiopia Human Rights Activists, 2014). To that end the Ethiopian government cannot phantom why Ethiopia is criticized for enacting a law with very similar provisions. While this claim of government holds some validity, there is a major departure in the implementation of these laws in the different jurisdictions identified. A major difference lie in the trial process of accused persons alleged to have committed or harboring the intention to commit terrorist acts. Ethiopian human rights activists argue that the process by which the anti-terrorism proclamation is interpreted and implemented makes the difference even if the law is copied verbatim from the US and Britain. They argue that 'suspects' are picked up by state security officials and detained at places unknown to family of 'suspects'. They are tortured and forced to make self-implicating confessions before being sent to the Police anti-terrorism unit and then processed for court after about four to eight months of inhumane ordeal (Ethiopia Human Rights Activists, 2014).

The Ethiopian government holds that the law does not necessarily imply a curtailment of civil liberties. It believes in media freedom and makes the case for the provision of the free press in Ethiopia's 1992 constitution. However, the Ethiopian government is critical of the private media. According to Genenew Assefa, a senior political advisor with the Ethiopian Office of Government Communication Affairs, the private media has failed to responsibly perform its role of educating the citizenry to make informed decisions. "... Unfortunately, for a good 10 years, in our democratic experience, the media did not, the private media that is, did not play such a role. There were serious problems of inaccuracy, irresponsibility, and shared naked political advocacy. For 10 years, my government tolerated this because it was the beginning democracy" (UNHCHR grills Ethiopia on Antiterror law, 2015).

Within the 10 years of Ethiopia government 'tolerance', evidence suggest otherwise. For instance, in 2004, the committee to projected 
journalists reported that for the second year running, Ethiopia has imprisoned more journalists than any other country on the African continent (UNHCHR grills Ethiopia on Anti-terror law, 2015). At least 20 Amharic-language newspapers were shut down in 2005 by the government. The government's view of what journalists call 'critical reporting' is reportage that will not be tolerated in any democracy. Genenew Assefa adds that "citizens were not being informed. They were being almost forced to rise up and tear up the system" (UNHCHR grills Ethiopia on Anti-terror law, 2015).

Considering the defense of the Ethiopian government at the United Nations office of the High Commissioner for Human Rights, it is suggestive that the rationale for the enactment of the anti-terrorism legislation was to control private press in Ethiopia rather than the actual fight against terrorism. Ethiopia is yet to experience how this proclamation has curtailed the activities of real terrorism in Ethiopia. While international human rights law has not been able to specifically define who a terrorist is, it is able to identify who is not a terrorist. For the most part, most of the convicts in the Ethiopia case hardly qualify to be terrorists, though they may qualify to be sanctioned under different domestic regulations.

\section{The importance of the right to freedom of expression for which it should not be lost}

The right of thought, opinion and expression plays a very important role among the various provisions in international human rights law. Not only is it necessary for its own sake but its role in the realization of related human rights, performance of civil duties and for the socioeconomic development of the state (Aidoo, 1993). It is difficult to imagine a functional democracy without the right to freedom of thought, opinion and expression. Human rights serve as a basis for a free and democratic society. It is hard to envision the realization of democratic principles such as accountability and transparency without the protection of human rights, especially the right to freedom of thought, opinion and expression (Aidoo, 1993). Hence the curtailment of the right in Ethiopia is most likely to negatively affect democratic development in the African country. It makes it difficult for the people to demand accountability from the government unless anyone wants to risk the consequesces of being prosecuted under the Proclamation. ${ }^{131}$ Political parties are unable to effectively organize to put a stong contest against the ruling party. The ruling political party's seemingly unrivalled power is gradually being felt by the people through the lack of judicial independence (Adinew, 2002). For democracy to consolidate in Ethiopia,

\footnotetext{
${ }^{131}$ This is evident from the many arrests, detentions and convictions of elements in Ethiopia who are critical of the ruling government for over two decades now.
} 
there is a need for the development of political parties and the media in freedom and security.

Further, the importance of the right is most felt where it does not exist. Thought, opinion and expression are the very basis of our human personality and social interaction. Without these, society cannot be sustained, let alone develop. This right actually allows the human being to freely do as he or she pleases within the confines of the laws of the state. It is further important for its relationship with other associated rights. It is related to other rights in such a manner that it gives effect to their realization. It provides the basis for the enjoyment of a range of rights (UN Human Rights Committee General Comment 34 par. 4, 2011). These rights include the right to liberty and the right of assembly, demonstration and petition (Constitution of Ethiopia Articles 17 and 30, 1994). Hence it follows from the cases that indeed the prosecution of suspects under the proclamation has not been limited to issues of expression but to those of related rights. For instance, the prosecution of politicians has been based not only on their speeches or demonstrations but also for doing so in the company of others as well as belonging to a political party. This proclamation has been a cancer eating up the rights enshrined in the Constitution and continues to threaten human rights and democracy in Ethiopia. Its effect is much broader and crippling than the effects on the right of thought, opinion and expression.

\section{Conclusion}

It is commendable that Ethiopia has taken steps to fight terrorism. Indeed the consequences of terrorism are much worse than the predicaments of the victims of the anti-terrorism legislation in Ethiopia. Nevertheless, the fight against terrorism is no justification for human rights abuses, especially those that tend to have no bearing on the fight like the unwarranted violation of the right of thought, opinion and expression. Using Ethiopia as a test case, names of states do not necessarily reflect democratic credentials. The Federal Democratic Republic of Ethiopia, suggestive of a democracy with decentralization of state power, and also a monist state, has proven to have negligible impact on the protection of the right of thought, opinion and expression.

Per the recommendations and the resolutions of the UN Special Rapporteur on the promotion and protection of human rights and fundamental freedoms it is safe to say that Ethiopia's measures towards countering terrorism run contrary to international human rights law ((Special Rapporteur on the Promotion and Protection of Human Rights and Fundamental Freedoms while Countering terrorism, 2015). First, the antiterrorism legislation pays little regards to both international human rights law and the rule of law. This is in spite of the fact that it seeks to ensure the 
safety and security of the people subject to the jurisdiction of Ethiopia. It violates not only the right of thought, opinion and expression but a number of other rights- the right to fair trial, freedom of movement and association, the right to actively participate in the governance of one's state, etc. The second point is very much related to the first. Contrary to the requirement that anti-terrorism measures should not be a basis for human rights violations, the very law upon which the Ethiopian state's efforts to counter terrorism violates human rights (Special Rapporteur on the Promotion and Protection of Human Rights and Fundamental Freedoms while Countering terrorism, 2015). One would wonder if the many prosecutions have actually reduced the scourge of terrorist attacks on Ethiopia. It is important to stress that, government measures and policies to counter terrorism take into serious consideration issues about the fundamental human rights of people the policies are meant to protect. This should be a lesson to countries that are considering legislation to address the challenges posed by terrorist networks.

\section{References:}

Adinew, Y. B. The Legitimacy of Restrictions on the Freedom of the Press under International Law with Special Reference to Ethiopia. Unpublished Master Thesis: University of Oslo, 2002.

Ahramonline. Ethiopia convicts 10 for 'links to Al-Qaeda'. 1st. January 2013. http://english.ahram.org.eg/NewsContent/2/8/61640/World/Region/Ethiopiaconvicts--for-links-to-AlQaeda.aspx (February 2nd, 2014).

Aidoo, Akwasi. "Africa: Democracy without Human Rights?" Human Rights Quarterly Vol. 15, No. 4., 1993: 703-715.

Asare, Bossman Eric. International Politics: The Beginner's Guide-Updated and Expanded. Accra.: Digibooks, 2016.

Bureau of Democracy, Human Rights, and Labor. Country Reports on Human Rights Practices: Ethiopia. 31. March 2003. http://m.state.gov/md18203.htm (February 12th, 2014).

Cassese, Antonio. International Law, (2nd Ed.). Oxford: Oxford University Press, 2005.

Combs, Cindy. Terrorism in the Twenty-First Century, (6th Ed.). Longman, USA, 2011.

Committee to Protect Journalists website. UNHCHR grills Ethiopia on antiterror law. (Accessed on Nov. 11, 2015) https://www.cpj.org/blog/2011/07/unhchr-grills-ethiopia-on-anti-terrorlaw.php Constitution, Federal Democratic Republic of Ethiopia. 1994.

Dagne, Ted. Africa and the War on Terrorism. Congressional Research Service Report for Congress, 2002. 
Donnelly, Jack. International Human Rights. Oxford: West View Press, 1993.

Duffy, Helen. The War on Terror and the Framework of International Law. New York: Cambridge University Press, 2007.

Ethiopia Human Rights Activists. "Rule of Law, Political Space and Human Rights in Ethiopia: A Closer look at the Anti-Terrorism Law." December 2014. ehrp.org/wp-content/.../03/Final-anti-terrorism-investigative-report.pdf (October 2015).

Federal Negarit Gazeta of the Federal Democratic Republic of Ethiopia. A Proclamation on Anti- Terrorism Proclamation No. 652/2009. August, 2009

Hessebon, Gedion. "Freedom of Expression in Ethiopia: The Jurisprudential Dearth." Mizan Law Review Vol. 4 No.2, Autumn 2010.

Human Rights Watch 2009. An Analysis of Ethiopia’s Draft Anti-Terrorism Law. (Updated June 30, 2009). Accessed on February 10th, 2014. https://www.hrw.org/news/2009/06/30/analysis-ethiopias-draft-antiterrorism-law

Human Rights Watch Submission on Ethiopia 2012. Report of the UN Special Rapporteur on human rights defenders to the General Assembly: Questionnaire on the use of legislation, including criminal legislation, to regulate the activities and work of human rights defenders.

Human Rights Watch Website. Ethiopia: Terrorism Law Decimates Media. (Accessed on January 20, 2014). https://www.hrw.org/news/2013/05/03/ethiopia-terrorism-law-decimatesmedia

Human Rights Watch Website. Ethiopia: Terrorism Law Used to Crush Free Speech. (Accessed on January 30, 2014). https://www.hrw.org/news/2012/06/27/ethiopia-terrorism-law-used-crushfree-speech

Keita, Mohamed. UNHCHR grills Ethiopia on Anti-Terror Law. 15th July 2011. https://www.cpj.org/blog/2011/07/unhchr-grills-ethiopia-on-antiterror-law.php (November 11th, 2015).

Khadiagala, Gilbert et. al. Terrorism in the Horn of Africa. Washington: United States Institute of Peace, January, 2004.

National Authorities, Ethiopia: Proclamation No. 652/2009 of 2009, AntiTerrorism Proclamation, 7 July 2009, available at: http://www.refworld.org/docid/4ba799d32.html (Accessed 11 November, 2014): Part 3, Preventive and Investigative Measures of the Proclamation.

Nickel, James W. Making Sense of Human Rights, 2nd edition. Oxford: Blackwell Publishing, 2007.

OAU Convention on the Prevention and Combating of Terrorism, 1999.Adopted at Algiers 
on 14 July 1999.Entry into force in accordance with Article 20. Depositary: Secretary-General of the Organization of African Unity Preventing and combating terrorism in Africa, www.africa-union.org

OHCHR. "Human Rights, Terrorism and Counter-terrorism." http://www.ohchr.org/Documents/Publications/Factsheet32EN.pdf (October 10, 2015).

Orend, Brian. Human Rights: Concept and Context. Ontario: Broadview Press, 2002.

Ploch, Lauren. Countering Terrorism in East Africa: The U.S. Response. Congressional Research Service, 2010.

Resolution adopted by the General Assembly on 19 December 2011 [on the report of the Third Committee (A/66/462/Add.2)] 66/171. Protection of human rights and fundamental freedoms while countering terrorism.

Special Rapporteur on the promotion and protection of human rights and fundamental freedoms while countering terrorism. http://www.ohchr.org/EN/Issues/Terrorism/Pages/SRTerrorismIndex.aspx (October 22nd, 2015).

Steiner Henry, Alston Philip and Goodknow, Ryan. International Human Rights in Context; Law, Politics and Morals. Oxford: Oxford University Press, 2008.

UN Committee on Economic, Social and Cultural Rights (CESCR), General Comment No. 3: The Nature of States Parties' Obligations (Art. 2, Para. 1, of the Covenant), 14 December 1990, E/1991/23,

The UN Global Counter Terrorism Review - preamble Resolution adopted by the General Assembly on 8 September 2010[without reference to a Main Committee (A/64/L.69)] 64/297. The United Nations Global CounterTerrorism Strategy https://www.un.org/en/terrorism/strategy-counterterrorism.shtml

UN General Assembly. International Covenant on Civil and Political Rights. (adopted and opened for signature, ratification and accession by general assembly resolution 2200A(XXI) on 16 December 1966).

UN Human Rights Committee. International Covenant on Civil and Political Rights General Comment Number 34, 102nd Session. Geneva, 11-29 July 2011. CCPR/C/GC/34

United Nations. United Nations General Assembly Adopts Global CounterTerrorism Strategy.September, 2006. https://www.un.org/en/terrorism/strategy-counter-terrorism.shtml (January 11th, 2014).

US Department of State mobile website. Country Reports on Human Rights Practices:

Ethiopia 2003. (Accessed on February 12, 2014). http://m.state.gov/md18203.htm 